\title{
STUDI SOSIAL POTENSI ENERGI PANAS BUMI DI KABUPATEN BANTUL
}

\author{
${ }^{1}$ Febriyanti Angelia Ginting, ${ }^{2}$ Syamsul Ma'arif, ${ }^{3}$ Wira Widyawidura \\ Universitas Proklamasi 45 Yogyakarta, Indonesia \\ Diterima Februari 2017; Disetujui April 2017, Dipublikasikan Juni 2017
}

\begin{abstract}
Abstrak
Kebutuhan energi di Indonesia khususnya energi listrik semakin meningkat seiring dengan perkembangan perekonomian dan meningkatnya jumlah penduduk di Indonesia. Di sisi lain, beberapa daerah di Indonesia belum mendapatkan pasokan energi listrik yang cukup. Walaupun energi listrik saat ini sudah menjadi kebutuhan vital untuk kehidupan sehari-hari, namun tidak semua orang dapat menikmati energi listrik. Pemandian Air Panas Parangwedang terletak di dusun Mancingan, Desa Parangtritis, Kecamatan Kretek, Kabupaten Bantul, DI Yogyakarta. Sumber air panas yang dihasilkan mengandung mineral terbesar antara lain $\mathrm{Na}$ (natrium), $\mathrm{Cl}$ (clorida), dan $\mathrm{Mg}$ (magnesium). Dalam pengembangan dan pengelolaan panas bumi di kawasan permukiman penduduk perlu dilakukan sosialisasi. Hal ini dilakukan karena pemahaman masyarakat yang berbeda-beda sehingga tidak menimbulkan penolakan.Diperlukan studi sosial untuk melihat kesiapan masyarakat di sekitar daerah Parangwedang jika dibangun pembangkit listrik tenaga panas bumi. Kearifan lokal yang ada di masyarakat dalam mengelola dan memanfaakan potensi panas bumi agar tidak berbenturan dengan pemanfaatan yang sudah ada yaitu di bidang pariwisata.
\end{abstract}

Kata Kunci : energi, panas bumi, studi sosial

\begin{abstract}
Energy demand in Indonesia, especially electricity, is increasing in line with economic development and increasing population in Indonesia. On the other hand, some regions in Indonesia have not received sufficient energy supply. Although electrical energy today has become a vital need for everyday life, but not everyone can enjoy electrical energy. Parangwedang Hot Water Bathing is located in Mancingan hamlet, Parangtritis Village, Kretek District, Bantul Regency, Dl Yogyakarta. The resulting hot springs contain the largest minerals such as $\mathrm{Na}$ (sodium), Cl (cloride), and $\mathrm{Mg}$ (magnesium). In the development and management of geothermal in the residential area the population needs to be socialized. This is done because the understanding of different communities so as not to cause rejection. Needed a social study to see the readiness of people around the area Parangwedang if built geothermal power plants. Local wisdom in the community in managing and utilizing geothermal potential so as not to clash with the existing utilization that is in the field of tourism.
\end{abstract}

Keywords: energy, geothermal, social studies

How to Cite : Ginting, A.,F, (2017). Studi Sosial Potensi Energi Panas Bumi Di Kabupaten Bantul 5 (1): 13-17

\begin{tabular}{lr}
\hline${ }^{*}$ Corresponding author: & P-ISSN-2549-9165 \\
E-mail: febriyanti.ginting@yahoo.co.id & e-ISSN -2580-2011
\end{tabular}




\section{PENDAHULUAN}

Meningkatnya kebutuhan energi dan tingginya harga minyak dunia telah memacu negara- negara untuk mengurangi ketergantungan minyak dengan memanfaatkan energi panas bumi. Geothermal merupakan energi yang paling bersih dibanding dengan energi fosil atau pun jenis energi terbarukan lainnya, karena dampak lingkunganyang ditimbulkan relatif tidak ada. Dewan Energi Nasional (DEN) dalam strategi Energi Indonesia mengemukakan bahwa Indonesia perlu menggunakan energi terbarukan untuk memenuhi target rasio listrik $100 \%$ di tahun 2020 dan menghapus ketergantungan impor energi. Upaya pengembangan pemanfaatan energi geothermal terus didukung dengan kebijakankebijakan baru.

Kebijakan terhadap pengelolaan energi dan sumberdaya mineral harus berwawasan kemasyarakatan dan lingkungan hidup yang didasarkan pada empat dasar yakni pemerataan dan keadilan, pendekatan integratif, wawasan jangka panjang, dan menghargai keanekaragaman perlu segera direalisasikan. Salah satu upaya untuk dapat melaksanakan pembangunan energi dan sumberdaya mineral yang berwawasan kemasyarakatan dan lingkungan hidup diperlukan keikutsertaan segenap pelakunya (stakeholder) dalam suatu kemitraan yang sinergis.

Sumber air panas Parang Wedang merupakan salah satu potensi pembangkit listrik tenaga panas bumi. Sumber air panas ini terletak di kawasan permukiman penduduk dan telah banyak dimanfaatkan sebagai objek pariwisata. jika dikelola dengan baik antara pemerintah dan masyarakat untuk memenuhi target rasio listrik maka ketergantungan Indonesia terhadap minyak akan berkurang. Pendekatan sosial ekonomi terhadap masyarakat sangat diperlukan untuk mengetahui kesiapan dan partisipasinya.

\section{METODE PENELITIAN}

Data-data yangdikumpulkan berupa data primer dan data sekunder. Data primerdikumpulkan melalui kuesioner, observasi dan wawancara. Wawancara dilakukan terhadapbeberapa informan dengan panduan berupa pedoman wawancara dengan jenispertanyaan terbuka. Sampel dalam penelitian ini terdiri dari 100 orang. Penentuan informan dilakukan secara purposive denganpertimbangan
1) Penduduk yang menetap di Parang Wedang dalam jangka waktu 5 tahun terakhir secara terus menerus, 2) mengetahui dan memahami hal-hal yang berkaitan dengan aspekpenelitian antara lain peran pemerintah daerah dan partisipasi masyarakat dalam pengembangan sumber air panas Parang Wedang.

Teknik analisis data pengelolaan tenaga panas bumi di Sumber Air Panas Parang Wedang Kabupaten Bantul menggunakan teknik kualitatif. Teknik kualitatif ini tidak menggunakan statistika sehingga hasil analisa jawaban responden tidak terikat pada skor dan skala tetapi dideskripsikan dan bersifat subjektif.

\section{HASIL DAN PEMBAHASAN}

Pemandian Air Panas Parang Wedang terletak di dusun Mancingan, Desa Parangtritis, Kecamatan Kretek, Kabupaten Bantul, DI Yogyakarta. Sumber air panas yang dihasilkan mengandung mineral terbesar antara lain $\mathrm{Na}$ (natrium), $\mathrm{Cl}$ (clorida), dan $\mathrm{Mg}$ (magnesium). Dalam pengembangan dan pengelolaan panas bumi di kawasan permukiman penduduk perlu dilakukan sosialisasi. Hal ini dilakukan karena pemahaman masyarakat yang berbeda-beda sehingga tidak menimbulkan penolakan.

Dari 100 orang sampel sebanyak 80 orang penduduk yang berada di Pemandian Air Panas Parang Wedang mengetahui bahwa sumber air panas Parang Wedang merupakan salah satu potensi pembangkit listrik tenaga panas bumi. 75 orang penduduk tidak pernah memanfaatkan potensi sumber air panas ini untuk keperluan pribadi maupun komersil. Hanya 5 orang penduduk yang memanfatkannya sebagai usaha komersil pemandian air panas.

Sebanyak 20 orang penduduk tidak mengetahui bahwa pemerintah turut serta dalam mengembangkan potensi air panas Parang Wedang dan 80 orang mengetahui peran serta pemerintah dalam pengembangan sumber air panas bersama masyarakat. Tetapi dari 80 orang penduduk yang mengetahui peran serta pemerintah dalam pengembangan air panas hanya 30 orang yang mengetahui ada peraturan yang diterapkan oleh pemerintah dalam pengembangannya. Selain itu hanya 50 penduduk yang mengetahui bahwa ada pihak luar yang turut serta bersama pemda mengelola potensi panas bumi ini. Dari hal ini disimpulkan bahwa 
perlunya sosialisasi dari pemerintah daerah kepada penduduk di sekitar sumber air panas Parang Wedang agar seluruh masyarakat mengetahui manfaat pengembangan panas bumi yang terdapat di sumber air panas Parang Wedang. Sehingga pengembangan potensi panas bumi di Parang Wedang dapat memberikan manfaat yang sebesar-besarnya bagi masyarakat.

Sebanyak 85 orang penduduk tidak pernah mendengar program pengelolaan panas bumi menjadi listrik untuk masyarakat yang dapat dimanfaatkan untuk mendorong usaha kecil/menengah. Para informan akan sangat mendukung program pemerintah daerah dan instansi/lembaga lainnya jika pengelolaan panas bumi menjadi listrik dapat mendorong usaha kecil.Adapun 15 orang yang pernah mendengar hanya memahami tenaga panas bumi dari sumber air panas dapat diubah menjadi listrik.

Ada yang setuju dan ada juga yang tidak setuju jika adanya program pengelolaan sumber air panas parang wedang menjadi energi listrik. Sebanyak 85 orang setuju dan 15 orang tidak setuju. bahkan 85 orang tersebut juga sangat setuju jika dibentuk sebuah lembaga yang membantu masyarakat untuk mengelola sumber air panas parang wedang menjadi energi listrik dan bersedia turut berpartisipasi mendukung pemerintah daerah dan lembaga lainnya untuk mengelola program pengelolaan panas bumi dan segera dapat terealisasi. 15 orang penduduk yang tidak setuju jika program pengelolaan sumber air panas parang wedang menjadi energi listrik dikarenakandapat mengurangi pendapatan mereka dari pengunjung pemandian air panas parang wedang. Mereka beranggapan bahwa pembangunan pembangkit listrik dapat merusak nilai-nilai historis di kawasan pemandian air panas.

Berdasarkanstudi, dalam pengembangan panas bumi sangat penting menerapkan prinsip kehati-hatian, menjaga dan membangun nilai kearifan lokal masyarakat di sekitar area pengembangan panas bumi. Hal ini yang menjadi PR (pekerjaan rumah) pemerintah daerah dan instansi/lembaga yang akan terlibat dalam pembangunan pembangkit listrik tenaga panas bumi. Tetap menjaga nilai historis kawasan pemandian air panas Parang Wedang. Dengan begitu, masyarakat akan semakin mudah untuk menerima pembangunan pembangkit listrik tenaga panas bumi.Dengan begitu, kita turut mendukung program pemerintah dalammenjaga keberlanjutan dan ketahanan energi nasional serta efisiensi dan efektifitas dalam UU No. 21 Tahun 2014 tentang panas bumi.

\section{ANALISIS SWOT}

Analisis SWOT merupakan metode perencanaan strategis yang digunakan untuk mengevaluasi kekuatan (strengths), kelemahan (weaknesses), peluang (opportunities), dan ancaman (threats) dalam suatu proyek atau suatu spekulasi bisnis pariwisata. Keempat faktor itulah yang membentuk akronim SWOT (strengths, weaknesses, opportunities, dan threats). Analisis SWOT dapat diterapkan dengan cara menganalisis dan memilah berbagai hal yang mempengaruhi keempat faktornya, kemudian menerapkannya dalam gambar matrik SWOT, dimana aplikasinya adalah bagaimana kekuatan (strengths) mampu mengambil keuntungan (advantage) dari peluang (opportunities) yang ada, bagaimana cara mengatasi kelemahan (weaknesses) yang mencegah keuntungan (advantage) dari peluang (opportunities)yang ada, selanjutnya bagaimana kekuatan (strengths) mampu menghadapi ancaman (threats) yang ada, dan terakhir adalah bagaimana cara mengatasi kelemahan (weaknesses) yang mampu membuat ancaman (threats) menjadi nyata atau menciptakan sebuah ancaman baru.

\begin{tabular}{|l|l|l|}
\hline Faktor Eksternal & Opportunity (Peluang) & Threats (Ancaman) \\
\cline { 2 - 3 } & $\begin{array}{l}\text { Sector pariwisata yang semakin } \\
\text { berkembang dan sangatdiminati } \\
\text { Berada di lokasi Parangtritis dan objek } \\
\text { wisata lainnya } \\
\text { Akses yang lancar dan baik } \\
\text { Masyarakat yang bersahabat }\end{array}$ & $\begin{array}{l}\text { Kurangnya } \\
\text { pemerintah } \\
\text { Pengunjung dalam jumlah yang } \\
\text { sangat banyak dalam satu waktu } \\
\text { di lokasi parang wedang sangat } \\
\text { rentan bagi bangunan yang } \\
\text { merupakan situs sejarah }\end{array}$ \\
\hline Strength (kekuatan) & SO & ST \\
\hline
\end{tabular}




\begin{tabular}{|c|c|c|}
\hline $\begin{array}{l}\text { Objek wisata bersifat edukatif } \\
\text { dan mengandung nilai-nilai } \\
\text { budaya yang tinggi yang masih } \\
\text { dipegang oleh masyarakat } \\
\text { sekitar pemandian air panas } \\
\text { parang wedang. } \\
\text { Keramahan masyarakat sekitar. }\end{array}$ & $\begin{array}{l}\text { Sektor pariwisata yang semakin } \\
\text { berkembang ditambah nilai-nilai yang } \\
\text { terkandung di dalam objek wisata } \\
\text { Parang wedang merupakan daya tarik } \\
\text { bagi wisatawan untuk datang kembali } \\
\text { Masyarakat yang bersahabat dan akses } \\
\text { yang lancar merupakan kunci utama } \\
\text { yang membuat wisatawan ingin } \\
\text { berkunjung kembali }\end{array}$ & $\begin{array}{l}\text { Walaupun pemerintah kurang } \\
\text { mendukung masyarakat dalam } \\
\text { pengembangan objek wisata } \\
\text { parang wedang belum menjadi } \\
\text { hambatan yang berarti bagi } \\
\text { pengelola parang wedang } \\
\text { didukung dengan sikap ramah } \\
\text { yang ditunjukkan pengelola } \\
\text { yang membuat pengunjung } \\
\text { ingin berkunjung kembali } \\
\text { Adanya konservasi nilai-nilai } \\
\text { budaya yang terkandung di } \\
\text { objek wisata dan pembatasan } \\
\text { jam berkunjung yang dilihat } \\
\text { dari jumlah pengunjung }\end{array}$ \\
\hline Weakness (Kelemahan) & WO & WT \\
\hline $\begin{array}{l}\begin{array}{l}\text { Debit air sangat } \\
\text { sehingga }\end{array} \text { rendah } \\
\text { terbatas } \\
\text { Kolam pemandian air panas } \\
\text { yang sudah pudar warna } \\
\text { dinding dan lantainya } \\
\text { Kurangnya atraksi wisata } \\
\text { seperti musik gamelan yang } \\
\text { membuat pengunjung merasa } \\
\text { rileks dan ingin datang kembali } \\
\text { Banyak pengunjung yang } \\
\text { merasa pusing jika berendam } \\
\text { lebih dari } 15 \text { menit di dalam } \\
\text { kolam walaupun bau belerang } \\
\text { tidak terasa semua masyarakat } \\
\text { Tidak dak semua } \\
\text { merasakan dampak ekonomi } \\
\text { dari adanya pemandian air } \\
\text { panas Parang Wedang }\end{array}$ & $\begin{array}{l}\text { Rehabilitasi dan pembangunan kolam } \\
\text { pemandian air panas parang wedang } \\
\text { Penambahan atraksi wisata seperti music } \\
\text { gamelan } \\
\text { Pembinaan masyarakat sadar wisata, } \\
\text { terutama disekitar Obyek Wisata } \\
\text { sehingga semua masyarakat merasakan } \\
\text { peningkatan ekonomi } \\
\text { Melakukan koordinasi dengan instansi } \\
\text { terkait kandungan belerang yang } \\
\text { terkandung di dalam air } \\
\text { Melakukan koordinasi dengan instansi } \\
\text { terkait untuk peningkatan mutu Obyek } \\
\text { Wisata }\end{array}$ & $\begin{array}{l}\text { Debit air yang sangat rendah } \\
\text { dengan jumlah pengunjung } \\
\text { yang sangat banyak dapat } \\
\text { diatasi dengan pembatasan } \\
\text { waktu berkunjung } \\
\text { Koordinasi dengan pemerintah } \\
\text { untuk meningkatkan kualitas } \\
\text { objek wisata parang wedang } \\
\text { sehingga meningkatkan } \\
\text { kuantitas pengunjung dan } \\
\text { kualitas fasilitas parang wedang. }\end{array}$ \\
\hline
\end{tabular}

Pengembangan pariwisata bertujuan untuk meningkatkan pendapatan devisa pada khususnya dan pendapatan negara dan masyarakat pada umumnya, perluasan kesempatan serta lapangan kerja dan mendorong kegiatan industri-industri penunjang dan industri sampingan lainnya, memperkenalkan dan mendayagunakan keindahan alam dan kebudayaan Indonesia dan meningkatkan persaudaraan atau persahabatan nasional dan internasional.

Dalam pengembangannya jika dilihat dari analisis SWOT di atas masih banyak yang perlu dibenahi untuk mengembangankan objek wisata Parang Wedang.Adanya sinergisme dan asosiasi antar Instansi terkait yang merupakan mitra kerja Pariwisata adalah dinas/badan sangat diperlukan dalam pengembangan pariwisata yang diharapkan mampu menjadi pariwisata yang berkelanjutan tanpa merusak lingkungan dan nilai-nilai budaya sekitar objek wisata Parang Wedang jika nantinya dibangun pembangkit listrik tenaga geothermal.

Ada beberapa upaya dalam pengembangan objek wisata di pemandian air panas Parang Wedang yaitu:

1. Pembenahan aspek fundamental pariwisata yaitu keamanan, kebersihan, ketertiban umum, keindahan dan sosial budaya

2. Diadakannya pembinaan kepada masyarakat juga pihak pihak terkait pengelolaan dan pengembangan objek wisata Parang Wedang sehingga mampu meningkatkan perekonomian masyarakat sekitar pemandian air panas Parang Wedang.

3. Peningkatan kemitraan antara berbagai instansi teknis pemerintah untuk mencapai tujuan pembangunan yang saling terkait.

4. Membina budaya sebagai asset pariwisata.

5. Mendorong pembangunan prasarana, sarana dan fasilitas wisata di objek wisata seperti 
lantai dan dinding kolam yang sudah tergerus dimakan usia

6. Menumbuh kembangkan sadar wisata di tengah-tengah masyarakat.

\section{SIMPULAN}

Segera terealisasinya pembangunan pembangkit listrik tenaga panas bumi sehingga dapat membantu dan mendorong usaha kecil/menengah. Minimnya pemahaman masyarakat tentang potensi panas bumi di sumber air panas Parang Wedang dusun Mancingan, Desa Parangtritis, Kecamatan Kretek, Kabupaten Bantul, Dl Yogyakarta. Tidak meratanya pemahaman masyarakat terhadap pengembangan program pengelolaan panas bumi menjadi listrik ı. Perlunya sosialisasi yang merata kepada masyarakat sekitar sumber air panas Parang Wedang dusun Mancingan, Desa Parangtritis, Kecamatan Kretek, Kabupaten Bantul, DI Yogyakarta agar memahami manfaat pengembangan panas bumi.

\section{DAFTAR PUSTAKA}

UU No 21 Tahun 2014 tentang panas bumi

WWF: Perhatikan Aspek Sosial Pengembangan Panas Bumi

(http://lampung.antaranews.com/berita/288000/w wf-perhatikan-aspek-sosial-pengembanganpanas-bumi), diakses 11 Mei 2017 